\title{
Isolation of Multipotent Mesenchymal Stem Cells from Human Extraocular Muscle Tissue
}

Amit Sharma ${ }^{1}$, Darilang Mawrie ${ }^{1}$, Damaris Magdalene ${ }^{2, *}$ and Bithiah Grace Jaganathan ${ }^{1, *}$

\author{
${ }^{1}$ Stem Cells and Cancer Biology Group, Department of Biosciences and Bioengineering, Guwahati, India; \\ ${ }^{2}$ Department of Pediatric Ophthalmology, Sri Sankaradeva Nethralaya, Guwahati, India \\ *For correspondence: drmaggie01@gmail.com; bithiahgi@iitg.ac.in
}

\begin{abstract}
[Abstract] Mesenchymal stem cells (MSCs) have attracted significant attention as potential therapeutic cells to treat various diseases ranging from tissue injuries, graft versus host disease, degenerative diseases and cancer. Since the initial discovery of MSCs in the bone marrow cells, MSCs have been successfully isolated from various adult and neo-natal tissues, albeit the procedures are often coupled with difficulties in harvesting tissue and produce low yield of cells, requiring extensive expansion in vitro. Here, we explored extra-ocular muscle tissues obtained from patients as a novel source of MSCs which express characteristic cell surface markers of MSCs and show multilineage differentiation potential with high proliferation capacity.
\end{abstract}

Keywords: Mesenchymal stem cells, Stem cells, Osteogenesis, Adipogenesis, Chondrogenesis, Extraocular muscle

[Background] Mesenchymal stem cells (MSCs) were originally identified as plastic adherent, fibroblastic cells derived from bone marrow and showed multi-lineage differentiation potential (Friedenstein et al., 1974a and 1974b). Over the years, MSCs have been implicated to play a role in a wide range of biological processes such as hematopoiesis (Friedenstein et al., 1974a), immunemodulation (Klyushnenkova et al., 2005; Crop et al., 2010), tissue repair, angiogenesis, tumorigenesis (Yagi and Kitagawa, 2013) and chemoresistance (Kumar et al., 2017). MSCs possess a vast secretome and have been heralded as factories of extracellular vesicles and "injury drug store" (Caplan and Correa, 2011) for their ability to produce a myriad number of growth factors and cytokines. The secreted factors of MSCs were found to have roles in tissue repair of renal (Grange et al., 2014; Zhang et al., 2014), neural (Koc et al., 2002; Zappia et al., 2005), liver (Li et al., 2013), lung (Lee et al., 2012), myocardial (Timmers et al., 2008; Bian et al., 2014) as well as ischemic injuries (Zhang et al., 2012). Therefore, MSCs are being explored as a therapeutic option for ameliorating various diseases such as myocardial infarction, respiratory disorders, Crohn's disease, graft versus host disease, diabetes, bone disorders, as well as liver cirrhosis (Uccelli et al., 2008; Battiwalla and Hematti, 2009; Luk et al., 2015).

Cells with similar properties of bone marrow derived MSCs (BM-MSCs) have since been isolated from placenta, amniotic fluid (Tsai et al., 2004), umbilical cord blood (Bieback et al., 2004), mobilized peripheral blood, adipose tissue (Kim et al., 2013), connective tissue, skeletal muscle (Young et al., 2001), dental (Gronthos et al., 2000), fetal tissue (Shin et al., 2009) and extra-ocular muscle tissue (Mawrie et al., 2016). This protocol explores extraocular muscle as a novel source of MSCs which is generally excised and discarded during strabismus correction surgery. Strabismus surgery is the third 
Please cite this article as: Sharma et. al., (2019). Isolation of Multipotent Mesenchymal Stem Cells from Human Extraocular Muscle Tissue,Bio-protocol 9

most common eye surgery in US with up to 1.2 million cases per year. The incised tissue is discarded after procedure, which can be used as a source of MSCs. Extraocular muscles are unaffected during Duchenne's muscular dystrophy (Kaminski et al., 1992; Khurana et al., 1995) and contain 15 times more side population stem cells than skeletal muscle (Pacheco-Pinedo et al., 2009). The extraocular muscle derived MSCs (EOM-MSCs) expressed CD73, CD90 and CD105 (Mawrie et al., 2016) which are characteristic cell surface markers for MSCs (Dominici et al., 2006) and could differentiate into all the three meseodermal lineages (Mawrie et al., 2016). Moreover, EOM-MSCs are relatively easy to isolate, have high proliferation capacity, neuroectodermal differentiation potential and might be a good candidate for stem cell based therapy for treating neurodegenerative disorders (Mawrie et al., 2016).

\section{Materials and Reagents}

1. Bio-hazard waste container (Tarsons, catalog number: 583254 )

2. Cell culture dish, $35 \times 10 \mathrm{~mm}$ (Eppendorf, catalog number: 0030700112)

3. Cryo-vials (Tarsons, catalog number: 523182)

4. Cryo-tags (Tarsons, Cryo-babies, catalog number: 526070)

5. FACS tubes (Corning, catalog number: 352063 )

6. Graduated centrifuge tubes, $15 \mathrm{ml}$ (Tarsons, catalog number: 546021 )

7. Graduated centrifuge tubes, $20 \mathrm{ml}$ (Tarsons, catalog number: 546041)

8. Graduated $20 \mu \mathrm{l}$ micro-tips (Tarsons, catalog number: 521000)

9. Graduated $200 \mu \mathrm{l}, 1,000 \mu \mathrm{l}$ micro-tips (Thermo Fisher Scientific, catalog numbers: 90030100 , 90030210-P)

10. Tissue culture treated, flat bottom 96-well plate (Eppendorf, catalog number: 6030730119)

11. Whatman filter paper (Whatman, catalog number: 1001 125)

12. $10 \mathrm{ml}$ serological glass pipettes (Himedia, catalog number: CG316-1 $\times 10 \mathrm{NO}$ )

13. Aseptic Petri dish (Tarsons, catalog number: 460051)

14. Sterile filtration unit $(0.22 \mu \mathrm{m})$ (Thermo Fisher Scientific, catalog number: $450-0020)$

15. Antibodies (Table 1) 
Please cite this article as: Sharma et. al., (2019). Isolation of Multipotent Mesenchymal Stem Cells from Human Extraocular Muscle Tissue,Bio-protocol 9

Table 1. Antibody details

\begin{tabular}{|c|c|c|c|c|c|}
\hline S. No. & Marker & Antibody & Manufacturer & Dilution & $\begin{array}{l}\text { Amount added per } 50 \\
\mu l \text { of FACS buffer }\end{array}$ \\
\hline 1. & CD29 & $\begin{array}{l}\text { Anti-human } \\
\text { CD29 PE }\end{array}$ & $\begin{array}{l}\text { BD Biosciences, catalog } \\
\text { number: } 555443\end{array}$ & $1: 100$ & $0.5 \mu \mathrm{l}$ \\
\hline 2. & CD34 & $\begin{array}{l}\text { Anti-human } \\
\text { CD34 FITC }\end{array}$ & $\begin{array}{l}\text { Thermo Fisher Scientific, } \\
\text { catalog number: CD3458101 }\end{array}$ & $1: 100$ & $0.5 \mu \mathrm{l}$ \\
\hline 3. & CD44 & $\begin{array}{l}\text { Anti-human } \\
\text { CD44 FITC }\end{array}$ & $\begin{array}{l}\text { BD Biosciences, } \quad \text { catalog } \\
\text { number: } 555478\end{array}$ & $1: 100$ & $0.5 \mu \mathrm{l}$ \\
\hline 4. & CD49e & $\begin{array}{l}\text { Anti-human } \\
\text { CD49e PE }\end{array}$ & $\begin{array}{l}\text { BD Biosciences, } \\
\text { number: } 555617\end{array}$ & $1: 100$ & $0.5 \mu \mathrm{l}$ \\
\hline 5. & CD73 & $\begin{array}{l}\text { Anti-human } \\
\text { CD73 PE }\end{array}$ & $\begin{array}{l}\text { BD Biosciences, catalog } \\
\text { number: } 550257\end{array}$ & $1: 100$ & $0.5 \mu \mathrm{l}$ \\
\hline 6. & CD90 & $\begin{array}{l}\text { Anti-human } \\
\text { CD90 FITC }\end{array}$ & $\begin{array}{l}\text { BD Biosciences, } \\
\text { number: } 555595\end{array}$ & $1: 100$ & $0.5 \mu \mathrm{l}$ \\
\hline 7. & CD105 & $\begin{array}{l}\text { Anti-human } \\
\text { CD105 PE }\end{array}$ & $\begin{array}{l}\text { BD Biosciences, catalog } \\
\text { number: } 560839\end{array}$ & $1: 100$ & $0.5 \mu \mathrm{l}$ \\
\hline 8. & HLA1 & $\begin{array}{l}\text { Anti-human } \\
\text { HLA1 FITC }\end{array}$ & $\begin{array}{l}\text { BD Biosciences, } \\
\text { number: } 555552\end{array}$ & $1: 100$ & $0.5 \mu \mathrm{l}$ \\
\hline 9. & $\begin{array}{l}\text { Isotype } \\
\text { control }\end{array}$ & $\begin{array}{l}\text { Anti-mouse } \\
\operatorname{lgG} 1 \mathrm{PE}\end{array}$ & BD, catalog number: 556561 & $1: 100$ & $0.5 \mu \mathrm{l}$ \\
\hline 10. & $\begin{array}{l}\text { Isotype } \\
\text { control }\end{array}$ & $\begin{array}{l}\text { Anti-mouse } \\
\text { IgG1 FITC }\end{array}$ & BD, catalog number: 554109 & $1: 100$ & $0.5 \mu \mathrm{l}$ \\
\hline
\end{tabular}

16. 10x Trypsin (2.5\%) (Thermo Fisher Scientific, catalog number: 15090-046)

17. Alizarin Red S (Sigma-Aldrich, catalog number: 199962)

18. Ascorbic acid-2-phosphate (Sigma-Aldrich, catalog number: A8960)

19. $\beta$-Glycerophosphate (Sigma-Aldrich, catalog number: G9891)

20. Dimethyl sulfoxide (DMSO) (Sigma-Aldrich, catalog number: D8418-250ML)

21. Dexamethasone (Sigma-Aldrich, catalog number: D2915)

22. Fibronectin solution (Sigma-Aldrich, Fibronectin human plasma, catalog number: F0895)

23. Formaldehyde solution $37-41 \%$ (w/v) (Merck, catalog number: 61780805001730 )

24. Hank's balanced salt solution (HBSS) (Sigma-Aldrich, catalog number: $55021 \mathrm{C}$ )

25. IBMX (Sigma-Aldrich, catalog number: I-5879)

26. Indomethacin (Sigma-Aldrich, catalog number: I-7378)

27. Insulin (Sigma-Aldrich, catalog number: 91077C)

28. Isopropanol (Merck, catalog number: 1.07022.2521)

29. Oil Red O (Sigma-Aldrich, catalog number: O-0625)

30. Potassium chloride (KCl) (Merck, catalog number: 61779205001730)

31. Potassium dihydrogen phosphate $\left(\mathrm{KH}_{2} \mathrm{PO}_{4}\right)$ (Merck, catalog number: 60487305001730)

32. Propidium lodide (Sigma-Aldrich, catalog number: P4170)

33. Safranin O (Sigma-Aldrich, catalog number: S8884)

34. Sodium bicarbonate (Sigma-Aldrich, catalog number: S5761) 
Please cite this article as: Sharma et. al., (2019). Isolation of Multipotent Mesenchymal Stem Cells from Human Extraocular Muscle Tissue,Bio-protocol 9

35. Sodium chloride ( $\mathrm{NaCl})$ (Merck, catalog number: 1.93206.0521)

36. Sodium dihydrogen phosphate $\left(\mathrm{NaH}_{2} \mathrm{PO}_{4}\right)$ (Merck, catalog number: 61787405001730)

37. DMEM-low glucose with L-Glutamine medium (Sigma-Aldrich, catalog number: D2902-1L)

38. DMEM-high glucose with L-Glutamine medium (Sigma-Aldrich, catalog number: D5648-1L)

39. Fetal Bovine Serum (Thermo Fisher Scientific, catalog number: 10270)

40. 100x Penicillin (10,000 Units/ml)-Streptomycin (10,000 Units/ml) antibiotic (Thermo Fisher Scientific, catalog number: 15140-122)

41. StemPro chondrogenesis differentiation kit (Thermo Fisher Scientific, catalog number: A1007101)

42. De-ionized water $\left(\mathrm{dH}_{2} \mathrm{O}\right)$ (Merck, Elix Type 2 pure water)

43. Trypan blue (Sigma-Aldrich, catalog number: T6146)

44. Liquid nitrogen $(99.999 \%)^{*}$

45. Sodium hydroxide $(\mathrm{NaOH})$ (Merck, catalog number: 61843805001730)

46. Hydrochloric acid 35\% ( $\mathrm{HCl}$ ) (Merck, catalog number: 61762505001730)

47. DMEM medium (see Recipes)

a. DMEM-LG (low glucose)/DMEM-HG (high glucose) basal medium

b. MSC growth medium

48. Tissue collection medium (see Recipes)

49. Fibronectin solution (see Recipes)

50. Phosphate buffered saline (PBS) (see Recipes)
a. 10x PBS
b. 1x PBS
c. PBS with $1 \mathrm{x}$ antibiotic

51. $1 x$ Trypsin $(0.25 \%)$ (see Recipes)

52. $0.4 \%$ trypan blue (see Recipes)

53. Heat-inactivated FBS (see Recipes)

54. Freezing media (see Recipes)

55. FACS buffer (see Recipes)

56. Propidium iodide staining solution (see Recipes)

57. Osteogenesis induction media (see Recipes)

58. Adipogenesis induction media (see Recipes)

59. $4 \%$ formaldehyde solution (see Recipes)

60. Alizarin red staining solution (see Recipes)

61. Oil Red O solution (see Recipes)
a. $1 \%$ Oil Red O stock solution
b. Oil red $O$ staining solution

62. Chondrogenic differentiation medium (see Recipes)

63. $0.1 \%$ Safranin $O$ staining solution (see Recipes) 


\section{Equipment}

1. Cryo-cooler (Tarsons, catalog number: 525000)

2. Sterilized sharp-tip forceps and scalpel

3. Analytical balance (Sartorius, Quintix Analytical Balance 60, $120 \mathrm{~g} \times 0.01,0.1 \mathrm{mg}$ )

4. Cryogenic cell storage container (International Cryogenics, model: D-2000C)

5. Biosafety level 2 cabinet (Thermo Fisher Scientific, model: 1300 series A2)

6. $\mathrm{CO}_{2}$ incubator (Thermo Fisher Scientific, Hera Cell 150i)

7. Flow cytometer (Becton Dickinson, FACS calibur and BD cell quest software)

8. Hemocytometer (Bright line hemocytometer) (Sigma-Aldrich, catalog number: Z359629)

9. Inverted microscope with camera (Zeiss, Axio Vert. A1)

10. Pipette controller (Socorex, Profiller 446)

11. Single-channel pipettes, $0.5-20 \mu \mathrm{l}, 20-200 \mu \mathrm{l}$, and 100-1,000 $\mu \mathrm{l}$ (Gilson, Pipetman classic)

12. Refrigerated centrifuge (Thermo Fisher Scientific, Sorvall legend X1R)

13. Water bath (Thermo Fisher Scientific, Labline water bath)

14. Ultra-low temperature freezer $\left(-80^{\circ} \mathrm{C}\right.$ freezer) (Thermo Fisher Scientific, Forma 88000 series)

15. $4{ }^{\circ} \mathrm{C}$ refrigerator*

16. $-20{ }^{\circ} \mathrm{C}$ freezer*

17. Autoclave*

*Note: These items can be ordered from any qualified company.

\section{Software}

1. FlowJo software (FlowJo, LLC)

\section{Procedure}

A. Isolation of extra ocular muscle derived MSCs (EOM-MSCs)

1. Collect excised EOM tissue (approximately $3-8 \mathrm{~mm}^{3}$ ) from the patient and transfer it to a vial with 3-4 $\mathrm{ml}$ of collection media (see Recipes). Use ice packs to maintain the tissue at low temperature during transportation.

Note: The following steps are to be performed inside a biosafety level 2 cabinet following aseptic culture techniques.

2. Before processing the tissue sample, coat the isolation dish with fibronectin at a concentration of $20 \mathrm{ng} / \mathrm{cm}^{2}$. To a $35 \mathrm{~mm}$ cell culture dish, add $500 \mu \mathrm{l}$ of fibronection solution $(400 \mathrm{ng} / \mathrm{ml}$; see Recipes) and incubate the dish at $37{ }^{\circ} \mathrm{C}$ in a $\mathrm{CO}_{2}$ incubator for $1 \mathrm{~h}$. Remove the excess fibronectin and rinse the dish once with $3 \mathrm{ml}$ of 1x PBS (see Recipes). 
Please cite this article as: Sharma et. al., (2019). Isolation of Multipotent Mesenchymal Stem Cells from Human Extraocular Muscle Tissue,Bio-protocol 9

3. Using sterile forceps, transfer the tissue to an aseptic Petri dish containing $10 \mathrm{ml}$ of PBS with $1 \mathrm{x}$ antibiotic (see Recipes). Incubate the tissue at room temperature for 5 min to disinfect and remove excess blood.

4. Carefully transfer the tissue to a sterile $35 \mathrm{~mm}$ cell culture dish coated with fibronectin and tear it into small pieces using sterile forceps or if required cut the tissue into small pieces with a sterile scalpel.

5. Add $500 \mu \mathrm{l}$ of warm fresh MSC growth medium (see Recipes) to the dish and allow the tissue pieces to attach by incubating the dish for $2 \mathrm{~h}$ in a $\mathrm{CO}_{2}$ incubator maintaining $5 \% \mathrm{CO}_{2}$ and $37^{\circ} \mathrm{C}$.

6. After $2 \mathrm{~h}$, add additional $2 \mathrm{ml}$ of warm MSC growth medium without disturbing the tissue pieces and return the dish to the incubator (Figure 1).

Note: Handle the plate gently during this time since the tissue can be dislodged easily by excessive shaking.

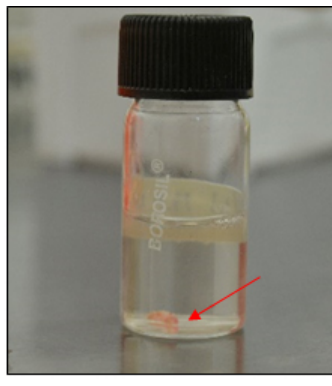

1. EOM tissue in tissue collection vial

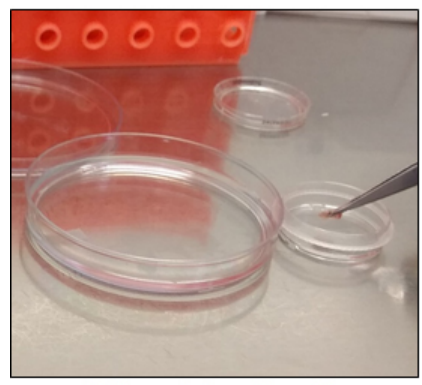

3. Tissue is transferred to fibronectin coated tissue culture dish
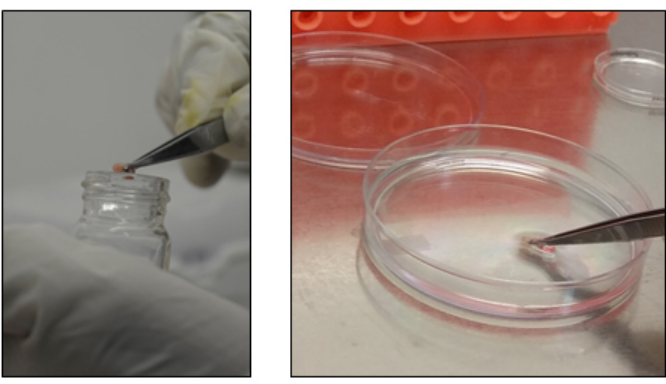

2. Tissue is transferred to a dish and rinsed with PBS containing antibiotics

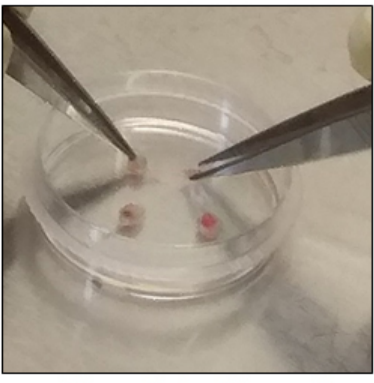

4. Tissue is torn into smal pieces with forceps

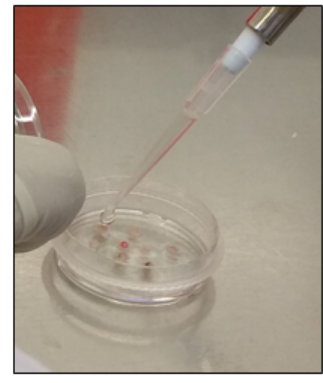

5. Growth media is added to the tissue

Figure 1. Procedure of processing EOM tissue

7. After $48 \mathrm{~h}$, carefully aspirate the medium and replenish with $1.5-2 \mathrm{ml}$ of fresh MSC growth medium (see Recipes) without disturbing/dislodging the tissue.

Note: MSC growth medium has to be replaced every $72 \mathrm{~h}$ thereafter.

8. After 7-10 days, check for attached cells around the explants using an inverted microscope (Figure 2). Ensure that the culture is free of any contamination at this point.

9. Once a sufficient number of attached cells (200-300 cells) are observed around the tissue pieces, gently remove the tissue explants using a fine tipped forceps without scrubbing the tissue over the dish surface (Figure 2). 
Notes:

a. Since most of the MSCs attach below the explants, care must be taken not to disturb the cells while removing the tissue.

b. Discard the tissue in a bio-hazard waste container. All the liquid waste should be appropriately disposed of after treatment with sodium hypochlorite.
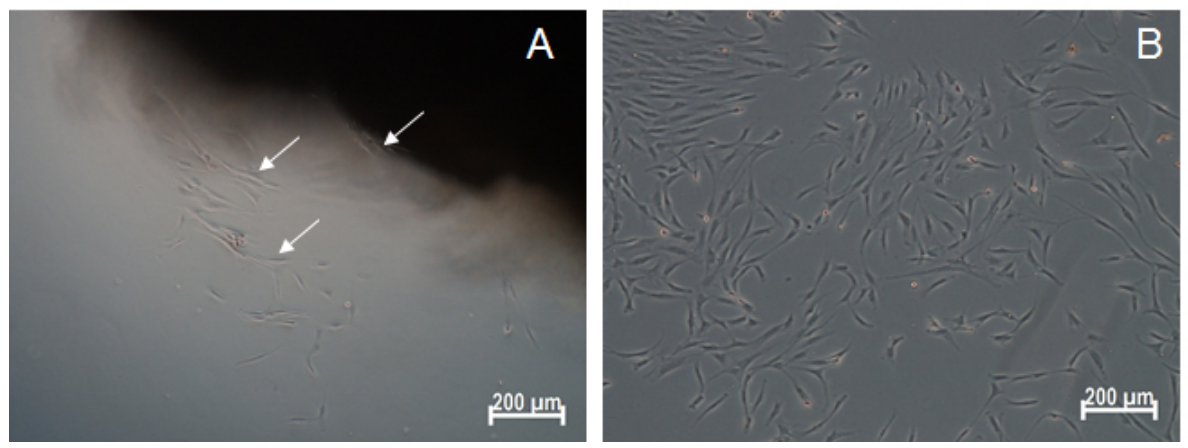

Figure 2. Microscopic image of isolated EOM-MSCs. A. Phase-contrast image showing the emergence of MSCs from the tissue explant within one week of isolation. White arrows represent the cells that have migrated out of the tissue. B. Phase contrast image of EOM-MSCs at passage 0 . Scale bars: $200 \mu \mathrm{m}$.

B. Maintenance of culture

Once the cell colonies reach $50 \%-80 \%$ confluence, sub-culture them as follows.

1. Aspirate the medium (spent medium) and collect it in a sterile $15 \mathrm{ml}$ centrifuge tube. Wash the cells twice with PBS.

2. Add $500 \mu \mathrm{l}$ of $1 \mathrm{x}$ trypsin (see Recipes) to the dish and incubate at $37^{\circ} \mathrm{C}$ for $5-7 \mathrm{~min}$. Notes:

a. Keep trypsin at room temperature for 5-10 min after retrieving from $4{ }^{\circ} \mathrm{C}$ before use.

b. Monitor the cell detachment intermittently under the microscope. Gentle taps on the side of the dish might be required to dislodge the rounded cells. Do not leave the cells in trypsin for more than $10 \mathrm{~min}$.

3. Add $1-2 \mathrm{ml}$ of spent medium to neutralize trypsin and transfer the cells to a labeled $15 \mathrm{ml}$ centrifuge tube.

4. Centrifuge at $300 \times g$ for $5 \mathrm{~min}$ at $4{ }^{\circ} \mathrm{C}$ to obtain the cell pellet. Discard the supernatant and resuspend the pellet in $1 \mathrm{ml}$ of fresh MSC growth medium.

5. Aliquot a small volume $(\sim 50 \mu \mathrm{l})$ of cells and add an equal volume of $0.4 \%$ trypan blue. Mix properly and count the viable cells using a hemocytometer.

6. Seed cells at $1-2 \times 10^{3}$ cells $/ \mathrm{cm}^{2}$ in a tissue culture dish and add $2 \mathrm{ml}$ of fresh MSC growth medium. Incubate the dish in $5 \% \mathrm{CO}_{2}$ incubator at $37^{\circ} \mathrm{C}$.

7. Change the MSC growth medium every $72 \mathrm{~h}$ until the cells attain $70 \%-80 \%$ confluence. Cells can be passaged up to 10-12 times by repeating the Steps B1-B6. 
C. Freezing and thawing of EOM-MSCs

1. After Step B5, re-suspend $1 \times 10^{6}$ cells in $0.5 \mathrm{ml}$ of pre-chilled sterile FBS (see Recipes).

2. Transfer the cell suspension to a labeled cryo-vial and add an equal volume of pre-chilled freezing media (see Recipes). Gently mix and transfer the vial immediately to a cryo-cooler.

3. Keep the cryo-cooler in a $-80{ }^{\circ} \mathrm{C}$ freezer for $24 \mathrm{~h}$ before transferring the vial to a cryogenic cell storage container with liquid nitrogen for long-term storage.

4. For reviving the cells, thaw by placing the cryo-vial immediately into a water bath at $37^{\circ} \mathrm{C}$ for 45-60 s.

5. Add $0.5 \mathrm{ml}$ of fresh warm MSC growth medium to the vial and transfer the cell suspension to a sterile $15 \mathrm{ml}$ centrifuge tube. Add additional $4 \mathrm{ml}$ of MSC growth medium drop-wise.

6. Centrifuge the cells at $300 \times g$ for $5 \mathrm{~min}$ at $4{ }^{\circ} \mathrm{C}$. Re-suspend the cell pellet in $1 \mathrm{ml}$ of fresh MSC growth medium to remove any remaining DMSO.

7. Count the viable cells as described in Step B5 and seed 2-3 $\times 10^{5}$ cells in a $35 \mathrm{~mm}$ cell culture dish with $2 \mathrm{ml}$ fresh MSC growth medium.

8. Replace the growth medium after $12 \mathrm{~h}$ and maintain the cells according to Step B7 thereafter.

D. Cell surface marker staining and flow cytometry

1. Trypsinize and count the EOM-MSCs as described in Procedure B.

Note: Keep the cells on ice during the whole procedure to maintain viability and reduce internalization of surface markers.

2. For each marker to be analyzed, distribute $1 \times 10^{5}$ cells per FACS tube for staining with fluorophore-labeled antibody. For each type of antibody used, keep additional FACS tube to be stained with a non-specific isotype control antibody as control.

3. Centrifuge the cells and wash the pellet twice with $3 \mathrm{ml}$ PBS.

Note: All centrifugation steps are to be done at $300 \times \mathrm{g}$ for 5 min at $4{ }^{\circ} \mathrm{C}$.

4. Resuspend the cells in $50 \mu$ of FACS buffer (see Recipes). Add $2 \mu l$ of diluted antibody (refer to antibody details in Table 1) followed by short gentle vortexing at low RPM. Incubate the tubes at $4{ }^{\circ} \mathrm{C}$ for $30 \mathrm{~min}$ in the dark.

5. Wash the cells with $1 \mathrm{ml}$ of FACS buffer and re-suspend in $300 \mu \mathrm{l}$ of propidium iodide staining buffer (see Recipes). Analyze the samples in a flow cytometer using proper gain/amp settings for the channels (Figure 3). 
A
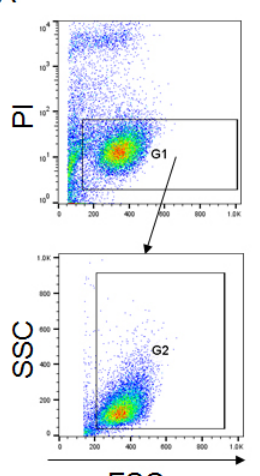

FSC
B

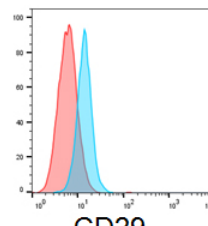

CD29

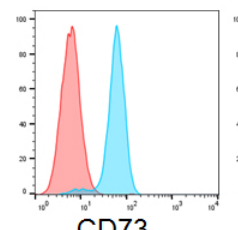

$\mathrm{CD} 73$

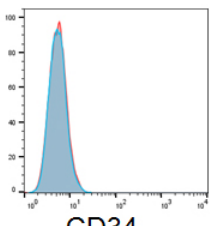

$\mathrm{CD} 34$

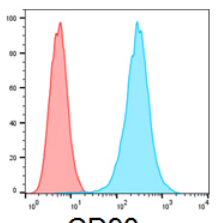

$\mathrm{CD} 90$

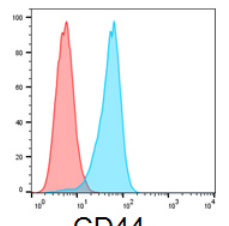

CD44

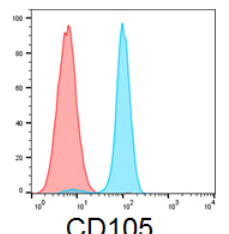

CD105
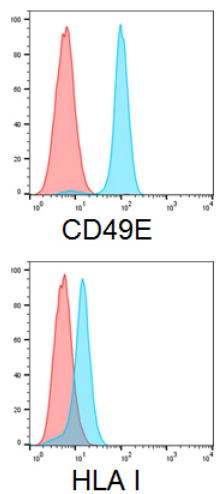

Figure 3. Cell surface marker expression of EOM-MSCs. A. Plots showing the gating for flow cytometry analysis; live cells were gated (G1) on the basis of propidium iodide (PI) negative (FL3 low) population in FL3 vs. FSC plot followed by gating (G2) in FSC vs. SSC plot to remove the cell debris. Cells in gate (G2) were further analyzed for their fluorescence intensity. B. EOMMSCs were stained with fluorescently conjugated antibodies against CD29, CD34, CD44, CD49E, CD73, CD90, CD105 and HLA class I, and the expression was analyzed by flow cytometry. The histogram in red represents the isotype control and blue represents the stained sample. Y-axis represents the number of events/counts and $\mathrm{X}$-axis represents the fluorescence intensity of the mentioned cell surface marker.

E. Osteogenic and adipogenic differentiation

1. Trypsinize and count the EOM-MSCs as described in Procedure B.

2. Seed EOM-MSCs at a density of $5,000 \mathrm{cells} / \mathrm{cm}^{2}$ for osteogenesis and $20,000 \mathrm{cells} / \mathrm{cm}^{2}$ for adipogenesis induction in a 96-well plate with adequate MSC growth medium (see Recipes).

3. After $24 \mathrm{~h}$, add osteogenesis or adipogenesis induction media (see Recipes) to the osteogenic and adipogenic conditions respectively.

4. Replace the induction media every 3-4 days and allow the cells to differentiate for 14-21 days.

F. Alizarin red staining for assessing calcium deposition during osteogenesis

1. Aspirate the medium and wash the cells twice with PBS.

2. Fix the cells in $4 \%$ formaldehyde solution (see Recipes) for $1 \mathrm{~h}$ at room temperature.

3. Wash the cells twice with $\mathrm{dH}_{2} \mathrm{O}$.

4. Stain with freshly prepared Alizarin red staining solution (see Recipes) for $10 \mathrm{~min}$ at room temperature.

5. Wash cells five times with $\mathrm{dH}_{2} \mathrm{O}$ followed by a wash with PBS for $15 \mathrm{~min}$ to remove excess stain. Add PBS to the cells to prevent them from drying.

6. Proceed to imaging the cells under an inverted microscope with a camera (Figure 4A).

G. Oil red $\mathrm{O}$ staining for assessing lipid accumulation during adipogenesis Note: Prepare Oil Red O staining solution (see Recipes) at least $1 \mathrm{~h}$ prior to staining. 
1. Aspirate the medium and wash the cells twice with PBS.

2. Fix the cells in $4 \%$ formaldehyde solution (see Recipes) for $1 \mathrm{~h}$ at room temperature.

3. Remove the fixing solution and rinse cells with $60 \%$ isopropanol in $\mathrm{dH}_{2} \mathrm{O}$.

4. Stain the cells with Oil Red O staining solution for $10 \mathrm{~min}$.

5. Wash cells five times with $\mathrm{dH}_{2} \mathrm{O}$. Add PBS to the cells to prevent them from drying.

6. Proceed to imaging the cells under an inverted microscope with a camera (Figure 4B).

H. Chondrogenic differentiation

1. Trypsinize and count the EOM-MSCs as described in Procedure B.

2. Re-suspend the pellet in an appropriate volume to generate a cell suspension of $1.6 \times 10^{7}$ cells $/ \mathrm{ml}$. Add a $5 \mu \mathrm{l}$ droplet of this cell suspension to the center of each well in a 96 -well plate and allow cells to attach by incubating the plate for $2 \mathrm{~h}$ in a $5 \% \mathrm{CO}_{2}$ incubator at $37^{\circ} \mathrm{C}$.

3. After $2 \mathrm{~h}$, add adequate $(100 \mu \mathrm{l})$ chondrogenic differentiation media (see Recipes) to the wells without disturbing the cell micromass and return the plate to the incubator.

4. Replace the chondrogenic media every 2 days and allow cells to differentiate for $>14$ days.

I. Safranin O staining for detection of cartilage, mucin and mast cell granules

1. Aspirate the medium and wash the cells twice with PBS.

2. Fix the cells with $4 \%$ formaldehyde solution (see Recipes) for $1 \mathrm{~h}$ at room temperature.

3. Wash the cells twice with $\mathrm{dH}_{2} \mathrm{O}$.

4. Stain with $0.1 \%$ safranin $O$ solution (see Recipes) for $5 \mathrm{~min}$ at room temperature.

5. Wash cells with $\mathrm{dH}_{2} \mathrm{O}$. Add $\mathrm{PBS}$ to the cells to prevent them from drying.

6. Proceed to imaging the cells under an inverted microscope with a camera (Figure 4C).
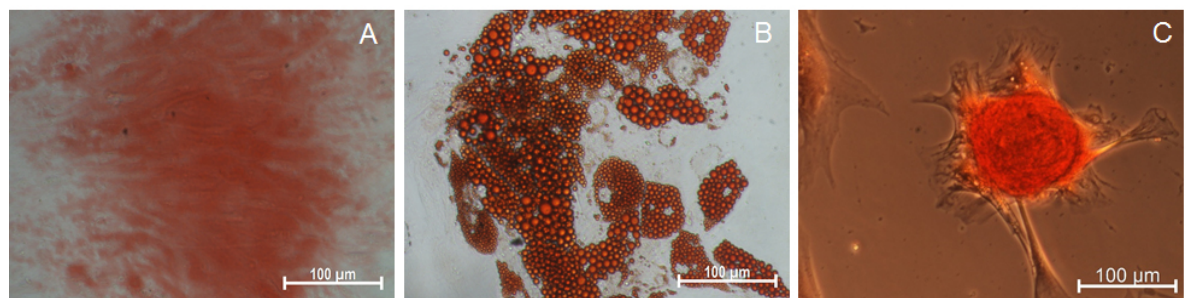

Figure 4. Differentiation of EOM-MSCs into osteogenic, adipogenic and chondrogenic cells. EOM-MSCs were seeded in the respective cell density and induction media for differentiation into osteogenic, adipogenic and chondrogenic lineage cells. The differentiated cells were stained with (A) alizarin red, (B) oil red o (C) safranin o for determining osteogenic, adipogenic and chondrogenic differentiation respectively. Scale bars: $100 \mu \mathrm{m}$.

\section{Data analysis}

The flow cytometry data for the expression of various surface markers on EOM-MSCs was analyzed using FlowJo software. Live cells were gated on the basis of propidium iodide negative (FL3 low) 
population in FL3 vs. FSC plot followed by gating in FSC vs. SSC plot to remove the cell debris. Histograms of signal in FL1 (for FITC-conjugated antibodies) and FL2 (for PE-conjugated antibodies) were plotted to define negative (unstained) and positive (stained) population using appropriate isotype-matched control antibody. This protocol shows representative data for only one of the EOMMSCs samples and does not include any statistical analysis.

\section{Recipes}

1. DMEM medium

a. DMEM-LG (low glucose)/DMEM-HG (high glucose) basal medium $10 \mathrm{~g}$ DMEM-LG or DMEM-HG media powder

$3.7 \mathrm{~g}$ sodium bicarbonate

$10 \mathrm{ml}$ 100x Penicillin-Streptomycin antibiotic solution

Make up the volume to $1 \mathrm{~L}$ with autoclaved deionized $\mathrm{H}_{2} \mathrm{O}$

Adjust $\mathrm{pH}$ to $\sim 7.0$ as $\mathrm{pH}$ tends to increase after filtration

Sterilize by filtration using a sterile filtration unit $(0.22 \mu \mathrm{m})$

Can be stored at $4{ }^{\circ} \mathrm{C}$ for up to 2 months

b. MSC growth medium

$10 \%$ FBS in DMEM-LG basal medium

Sterilize by filtration using a sterile filtration unit $(0.22 \mu \mathrm{m})$

Store at $4{ }^{\circ} \mathrm{C}$ and use within two weeks

2. Tissue collection medium

2x Penicillin-Streptomycin antibiotic in DMEM-LG basal medium or HBSS solution

3. Fibronectin solution $(400 \mathrm{ng} / \mathrm{ml})$

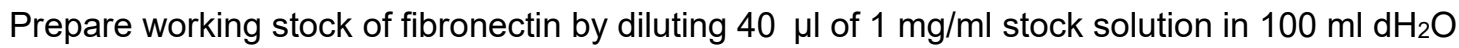
Sterilize by filtration using a sterile filtration unit $(0.22 \mu \mathrm{m})$ and store at $4{ }^{\circ} \mathrm{C}$

4. Phosphate buffered saline (PBS)

a. 10x PBS

$80 \mathrm{~g} \mathrm{NaCl}$

$2 \mathrm{~g} \mathrm{KCl}$

$14.4 \mathrm{~g} \mathrm{Na}_{2} \mathrm{HPO}_{4}$

$2.4 \mathrm{~g} \mathrm{KH}_{2} \mathrm{PO}_{4}$

Make up the volume to $1 \mathrm{~L}$ with autoclaved $\mathrm{dH}_{2} \mathrm{O}$

Sterilize by filtration using a sterile filtration unit $(0.22 \mu \mathrm{m})$

Store at room temperature

b. $1 \times$ PBS

Dilute 10x PBS ten times ( $1 \mathrm{ml}$ in $10 \mathrm{ml}$ ) in $\mathrm{H}_{2} \mathrm{O}$

Adjust $\mathrm{pH}$ to 7.4 and autoclave at $121^{\circ} \mathrm{C}$ for $40 \mathrm{~min}$ 
c. PBS with $1 \mathrm{x}$ antibiotic

$100 \mu \mathrm{l}$ of $100 x$ Penicillin-Streptomycin antibiotic in $10 \mathrm{ml}$ of $1 \times$ PBS

5. $1 x \operatorname{Trypsin}(0.25 \%)$

Dilute 10x trypsin ten times in sterile cold 1x PBS (1 $\mathrm{ml}$ of 10x trypsin in $9 \mathrm{ml}$ of PBS) and prepare $5 \mathrm{ml}$ aliquots for use

Store aliquots at $-20^{\circ} \mathrm{C}$ for long term storage. Thaw at room temperature and store at $4{ }^{\circ} \mathrm{C}$ after use for up to 1 week

6. $0.4 \%$ trypan blue

Dissolve $50 \mathrm{mg}$ of Trypan blue (dye composition $40 \%$ ) in $5 \mathrm{ml}$ of $1 \mathrm{x}$ PBS

Sterilize by filtration using a sterile filtration unit $(0.22 \mu \mathrm{m})$

Store as aliquots at $4{ }^{\circ} \mathrm{C}$

7. Heat inactivated FBS

Heat inactivate FBS by incubating at $56{ }^{\circ} \mathrm{C}$ for $1 \mathrm{~h}$ in a water bath and store at $-20^{\circ} \mathrm{C}$ as $50 \mathrm{ml}$ aliquots

8. Freezing media

$20 \%$ DMSO in heat-inactivated FBS ( $1 \mathrm{ml}$ DMSO in $4 \mathrm{ml}$ of FBS)

9. FACS buffer

$2 \%$ heat-inactivated FBS in $1 \times$ PBS $(200 \mu$ FBS in $9.8 \mathrm{ml}$ of PBS $)$

10. Propidium iodide staining solution

$2 \mu \mathrm{g} / \mathrm{ml}$ of propidium iodide in FACS buffer

11. Osteogenesis induction media

DMEM-high glucose basal medium

1x Penicillin-Streptomycin antibiotic

$10 \%$ FBS

$10 \mathrm{mM}$ ß-Glycerophosphate

$0.1 \mu \mathrm{M}$ Dexamethasone

0.05 mM Ascorbic acid-2-phosphate

Note: Osteogenesis induction media can be stored for up to 4 weeks at $4{ }^{\circ} \mathrm{C}$.

12. Adipogenesis induction media

DMEM-high glucose basal medium

1x Penicillin-Streptomycin antibiotic

$10 \%$ FBS

$1 \mu \mathrm{M}$ Dexamethasone

$0.2 \mathrm{mM}$ Indomethacin (add 2 drops of $5 \mathrm{M} \mathrm{NaOH}$ to dissolve)

$0.5 \mathrm{mM}$ IBMX

$0.01 \mathrm{M}$ Insulin (add 2 drops of $5 \mathrm{M} \mathrm{HCl}$ to dissolve)

Note: Adipogenesis induction media can be stored for up to 4 weeks at $4{ }^{\circ} \mathrm{C}$.

13. $4 \%$ formaldehyde solution

Dilute $37 \%-41 \%$ Formaldehyde solution 10 times in $1 \times$ PBS 
$1 \mathrm{ml}$ of $37 \%-41 \%$ Formaldehyde solution

$9 \mathrm{ml}$ of $1 \mathrm{x}$ PBS

14. Alizarin red staining solution

\section{$0.19 \mathrm{~g}$ Alizarin Red S}

$10 \mathrm{ml} \mathrm{dH_{2 } \mathrm { O }}$

Adjust $\mathrm{pH}$ to 4.2

15. Oil Red O solution

a. $1 \%$ Oil Red O stock solution

$1 \mathrm{~g}$ Oil Red O

$100 \mathrm{ml}$ isopropanol

Warm in a water bath at $56{ }^{\circ} \mathrm{C}$ for $30-60 \mathrm{~min}$. Not all of Oil Red O will dissolve

Can be stored at room temperature for up to 6 months

b. Oil red $O$ staining solution

3 parts of $1 \%$ Oil Red O stock solution

2 parts of $\mathrm{dH}_{2} \mathrm{O}$

Mix and let stand for $1 \mathrm{~h}$

Filter the solution with Whatman filter paper

16. Chondrogenic differentiation medium

$10 \mathrm{ml}$ 10x Stem Pro Chondrogenesis supplement

$90 \mathrm{ml}$ Stem Pro Osteocyte/Chondrocyte Differentiation Basal Medium

1x Penicillin-Streptomycin antibiotic

Note: Chondrogenic differentiation media can be stored for up to 4 weeks at $4{ }^{\circ} \mathrm{C}$.

17. $0.1 \%$ Safranin $O$ staining solution

\section{$0.1 \mathrm{~g}$ Safranin $\mathrm{O}$}

$100 \mathrm{ml} \mathrm{dH_{2 } \mathrm { O }}$

Stir to help dissolve

\section{Acknowledgments}

This work was supported by funds from Indian Council for Medical Research (ICMR), Govt. of India. Protocol was adapted from Mawrie et al. (2016). The authors thank Trishna Anand and Vishnu for their assistance in imaging.

\section{Competing interests}

The authors declare no competing interests. 
Please cite this article as: Sharma et. al., (2019). Isolation of Multipotent Mesenchymal Stem Cells from Human Extraocular Muscle Tissue,Bio-protocol 9

\section{Ethics}

The study was approved by ethics committee of IIT Guwahati and samples were collected after written informed consent from the patients.

\section{References}

1. Battiwalla, M. and Hematti, P. (2009). Mesenchymal stem cells in hematopoietic stem cell transplantation. Cytotherapy 11(5): 503-515.

2. Bian, S. Y., Zhang, L. P., Duan, L. F., Wang, X., Min, Y. and Yu, H. P. (2014). Extracellular vesicles derived from human bone marrow mesenchymal stem cells promote angiogenesis in a rat myocardial infarction model. J Mol Med-Jmm 92(4): 387-397.

3. Bieback, K., Kern, S., Kluter, H. and Eichler, H. (2004). Critical parameters for the isolation of mesenchymal stem cells from umbilical cord blood. Stem Cells 22(4): 625-634.

4. Caplan, A. I. and Correa, D. (2011). The MSC: An injury drugstore. Cell Stem Cell 9(1): 11-15.

5. Crop, M. J., Baan, C. C., Korevaar, S. S., ljzermans, J. N. M., Weimar, W. and Hoogduijn, M. J. (2010). Human adipose tissue-derived mesenchymal stem cells induce explosive T-cell proliferation. Stem Cells Dev 19(12): 1843-1853.

6. Dominici, M., Le Blanc, K., Mueller, I., Slaper-Cortenbach, I., Marini, F. C., Krause, D. S., Deans, R. J., Keating, A., Prockop, D. J. and Horwitz, E. M. (2006). Minimal criteria for defining multipotent mesenchymal stromal cells. The international society for cellular therapy position statement. Cytotherapy 8(4): 315-317.

7. Friedenstein, A. J., Chailakhyan, R. K., Latsinik, N. V., Panasyuk, A. F. and Keilissb.Iv (1974a). Stromal cells responsible for transferring microenvironment of hematopoietic tissues. Cloning in vitro and retransplantation in vivo. Transplantation 17(4): 331-340.

8. Friedenstein, A. J., Deriglasova, U. F., Kulagina, N. N., Panasuk, A. F., Rudakowa, S. F., Luria, E. A. and Rudakow, I. A. (1974b). Precursors for fibroblasts in different populations of hematopoietic cells as detected by in vitro colony assay method. Exp Hematol 2(2): 83-92.

9. Grange, C., Tapparo, M., Bruno, S., Chatterjee, D., Quesenberry, P. J., Tetta, C. and Camussi, G. (2014). Biodistribution of mesenchymal stem cell-derived extracellular vesicles in a model of acute kidney injury monitored by optical imaging. Int J Mol Med 33(5): 1055-1063.

10. Gronthos, S., Mankani, M., Brahim, J., Robey, P. G. and Shi, S. (2000). Postnatal human dental pulp stem cells (DPSCs) in vitro and in vivo. Proc Natl Acad Sci U S A 97(25): 13625-13630.

11. Kaminski, H. J., al-Hakim, M., Leigh, R. J., Katirji, M. B. and Ruff, R. L. (1992). Extraocular muscles are spared in advanced Duchenne dystrophy. Ann Neurol 32(4): 586-588.

12. Khurana, T. S., Prendergast, R. A., Alameddine, H. S., Tome, F. M., Fardeau, M., Arahata, K., Sugita, H. and Kunkel, L. M. (1995). Absence of extraocular muscle pathology in Duchenne's muscular dystrophy: role for calcium homeostasis in extraocular muscle sparing. J Exp Med 182(2): 467-475. 
Please cite this article as: Sharma et. al., (2019). Isolation of Multipotent Mesenchymal Stem Cells from Human Extraocular Muscle Tissue,Bio-protocol 9

13. Kim, J., Escalante, L. E., Dollar, B. A., Hanson, S. E. and Hematti, P. (2013). Comparison of breast and abdominal adipose tissue mesenchymal stromal/stem cells in support of proliferation of breast cancer cells. Cancer Invest 31(8): 550-554.

14. Klyushnenkova, E., Mosca, J. D., Zernetkina, V., Majumdar, M. K., Beggs, K. J., Simonetti, D. W., Deans, R. J. and Mclntosh, K. R. (2005). T cell responses to allogeneic human mesenchymal stem cells: immunogenicity, tolerance, and suppression. J Biomed Sci 12(1): 4757.

15. Koc, O. N., Day, J., Nieder, M., Gerson, S. L., Lazarus, H. M. and Krivit, W. (2002). Allogeneic mesenchymal stem cell infusion for treatment of metachromatic leukodystrophy (MLD) and Hurler syndrome (MPS-IH). Bone Marrow Transplant 30(4): 215-222.

16. Kumar, A., Bhattacharyya, J. and Jaganathan, B. G. (2017). Adhesion to stromal cells mediates imatinib resistance in chronic myeloid leukemia through ERK and BMP signaling pathways. Sci Rep 7(1): 9535.

17. Lee, C., Mitsialis, S. A., Aslam, M., Vitali, S. H., Vergadi, E., Konstantinou, G., Sdrimas, K., Fernandez-Gonzalez, A. and Kourembanas, S. (2012). Exosomes mediate the cytoprotective action of mesenchymal stromal cells on hypoxia-induced pulmonary hypertension. Circulation 126(22): 2601-2611.

18. Li, T. F., Yan, Y. M., Wang, B. Y., Qian, H., Zhang, X., Shen, L., Wang, M., Zhou, Y., Zhu, W., Li, W. and Xu, W. R. (2013). Exosomes derived from human umbilical cord mesenchymal stem cells alleviate liver fibrosis. Stem Cells Dev 22(6): 845-854.

19. Luk, F., de Witte, S. F. H., Bramer, W. M., Baan, C. C. and Hoogduijn, M. J. (2015). Efficacy of immunotherapy with mesenchymal stem cells in man: a systematic review. Expert Rev Clin Immunol 11(5): 617-636.

20. Mawrie, D., Kumar, A., Magdalene, D., Bhattacharyya, J. and Jaganathan, B. G. (2016). Mesenchymal stem cells from human extra ocular muscle harbor neuroectodermal differentiation potential. Plos One 11(6): e0156697.

21. Pacheco-Pinedo, E. C., Budak, M. T., Zeiger, U., Jorgensen, L. H., Bogdanovich, S., Schroder, H. D., Rubinstein, N. A. and Khurana, T. S. (2009). Transcriptional and functional differences in stem cell populations isolated from extraocular and limb muscles. Physiol Genomics 37(1): 3542.

22. Shin, K. S., Na, K. H., Lee, H. J., Kim, D. G., Shin, S. J., Kim, J. K. and Kim, G. J. (2009). Characterization of fetal tissue-derived mesenchymal stem cells. Int J Stem Cells 2(1): 51-58.

23. Timmers, L., Lim, S. K., Arslan, F., Armstrong, J. S., Hoefer, I. E., Doevendans, P. A., Piek, J. J., El Oakley, R. M., Choo, A., Lee, C. N., Pasterkamp, G. and de Kleijn, D. P. V. (2008). Reduction of myocardial infarct size by human mesenchymal stem cell conditioned medium. Stem Cell Res 1(2): 129-137.

24. Tsai, M. S., Lee, J. L., Chang, Y. J. and Hwang, S. M. (2004). Isolation of human multipotent mesenchymal stem cells from second-trimester amniotic fluid using a novel two-stage culture protocol. Hum Reprod 19(6): 1450-1456. 
Please cite this article as: Sharma et. al., (2019). Isolation of Multipotent Mesenchymal Stem Cells from Human Extraocular Muscle Tissue,Bio-protocol 9

25. Uccelli, A., Moretta, L. and Pistoia, V. (2008). Mesenchymal stem cells in health and disease. Nat Rev Immunol 8(9): 726-736.

26. Yagi, H. and Kitagawa, Y. (2013). The role of mesenchymal stem cells in cancer development. Front Genet 4: 261.

27. Young, H. E., Steele, T. A., Bray, R. A., Hudson, J., Floyd, J. A., Hawkins, K., Thomas, K., Austin, T., Edwards, C., Cuzzourt, J., Duenzl, M., Lucas, P. A. and Black, A. C. (2001). Human reserve pluripotent mesenchymal stem cells are present in the connective tissues of skeletal muscle and dermis derived from fetal, adult, and geriatric donors. Anat $\operatorname{Rec} 264(1)$ : 51-62.

28. Zappia, E., Casazza, S., Pedemonte, E., Benvenuto, F., Bonanni, I., Gerdoni, E., Giunti, D., Ceravolo, A., Cazzanti, F., Frassoni, F., Mancardi, G. and Uccelli, A. (2005). Mesenchymal stem cells ameliorate experimental autoimmune encephalomyelitis inducing T-cell anergy. Blood 106(5): 1755-1761.

29. Zhang, G. Y., Zou, X. Y., Miao, S., Chen, J. J., Du, T., Zhong, L., Ju, G. Q., Liu, G. H. and Zhu, Y. J. (2014). The anti-oxidative role of micro-vesicles derived from human Wharton-Jelly mesenchymal stromal cells through NOX2/gp91(phox) suppression in alleviating renal ischemia-reperfusion injury in rats. Plos One 9(3): e92129.

30. Zhang, H. C., Liu, X. B., Huang, S., Bi, X. Y., Wang, H. X., Xie, L. X., Wang, Y. Q., Cao, X. F., Lv, J., Xiao, F. J., Yang, Y. and Guo, Z. K. (2012). Microvesicles derived from human umbilical cord mesenchymal stem cells stimulated by hypoxia promote angiogenesis both in vitro and in vivo. Stem Cells Dev 21(18): 3289-3297. 